\title{
Towards a better understanding of the cellular basis for cerebrospinal fluid shunt obstruction: report on construction of a bank of explanted hydrocephalus devices
}

\author{
Brian W Hanak ${ }^{1 *}$, Emily F Ross ${ }^{1}$, Carolyn A Harris ${ }^{2}$, Samuel R Browd ${ }^{1}$, William Shain ${ }^{1}$ \\ From Hydrocephalus 2015 \\ Banff, Canada. 18-21 September 2015
}

\section{Introduction}

Shunt obstruction with cells/tissue is the most common cause of shunt failure; with ventricular catheter obstruction, alone, accounting for $>50 \%$ of pediatric failures. We sought to systematically collect explanted ventricular catheters from Seattle Children's Hospital with a focus on elucidating cellular mechanisms underlying obstruction.

\section{Methods}

In the operating room explanted hardware was placed in $4 \%$ paraformaldehyde. Weekly, samples were transferred to buffer solution and stored at $4^{\circ} \mathrm{C}$. After obtaining consent/assent, catheters were labeled using cell-specific markers for astrocytes (monoclonal rat anti-glial fibrillary acidic protein), microglia (monoclonal rabbit anti-Iba1), and choroid plexus (polyclonal chicken anti-transthyretin) for $24 \mathrm{hrs}$. These targets were visualized using goat antirat Alexa 488, goat anti-rabbit Alexa 594, and goat antichicken Alexa 647 conjugated secondary antibodies, which were applied for $24 \mathrm{hrs}$ in conjunction with a nuclear stain (Hoechst). Catheters were mounted in custom polycarbonate imaging chambers. Three-dimensional, multispectral spinning disk confocal microscopy was utilized to image catheters (Olympus, IX81 inverted microscope, motorized stage, charged-coupled camera).

\section{Results}

Intraoperatively confirmed ventricular catheter obstruction was the leading cause of shunt failure, noted in 53.6\% of cases. Shunt hardware was explanted in 321 surgeries

\footnotetext{
* Correspondence: hanakb@uw.edu

'University of Washington, Seattle, WA, USA

Full list of author information is available at the end of the article
}

during the study period $(4 / 1 / 13-11 / 30 / 14)$ and we received hardware in $34.0 \%$ of cases. Our consent rate for explanted ventricular catheters was $58.2 \%$. Bugbee wire monopolar electrocautery was used on $26.1 \%$ of explanted catheters. Over 30 ventricular catheters have been imaged to date, resulting in the following observations: 1) Astrocytes and microglia are the dominant cell types bound directly to catheter surfaces; 2) Cellular binding to catheters is ubiquitous even if no grossly visible tissue is apparent; 3) Commercially available catheters contain rough, irregular surfaces, particularly at CSF intake holes, and there appears to be preferential cell binding to these rough surfaces; 4) Immunohistochemistry techniques are of limited utility when a catheter has been exposed to Bugbee wire electrocautery.

\section{Conclusions}

Ventricular catheter occlusion remains a significant source of shunt morbidity in the pediatric population and, given their ability to intimately associate with catheter surfaces, astrocytes and microglia appear to be critical to this pathophysiology. Reduced shunt failure rates may be possible through improved ventricular catheter design. Work is ongoing to fabricate catheters with smooth CSF intake portals and altered surface chemistry, with the goal of making catheters a less favorable substrate for cell attachment.

\section{Authors' details}

${ }^{1}$ University of Washington, Seattle, WA, USA. ${ }^{2}$ Wayne State University, Detroit, MI, USA.

Published: 18 September 2015 


\section{References}

1. Peterson EC, Hanak B, Morton RP, Osbun J, Levitt MR, Kim LJ: Are Aneurysms Treated with Balloon Assisted Coiling and Stent Assisted Coiling Different? Morphological Analysis of 113 Unruptured Wide Necked Aneurysms Treated with Adjunctive Devices. Neurosurgery 2014, 75:145-51, PMID: 24739363.

2. Morton R, Hanak B, Levitt M, Tozer K, Peterson E, Vilela M, Kim L, Chesnut R: Blunt Traumatic Occlusion of the Carotid and Vertebral Arteries. J Neurosurg. J Neurosurg 2014, 120:1446-50, PMID: 24678781.

3. Hanak BW, Walcott BP, Nahed BV, Muzikansky A, Mian MK, Kimberly WT, Curry WT: Post-Operative Intensive Care Unit Requirements Following Elective Craniotomy. World Neurosurg 2014, 81:165-72, PMID: 23182731.

4. Hanak BW, Zada G, Nayar W, Thiex R, Du R, Day AL, Laws ER: Cerebral aneurysms with intrasellar extension: a systematic review of clinical, anatomical, and treatment characteristics. J Neurosurg 2012, 116:164-78, PMID: 22054212.

5. Hanak BW, Walcott BP, Codd PJ, Jones PS, Nahed BV, Butler WE, Asaad WF: Fourth ventricular neurocystercercosis presenting with acute hydrocephalus. J Clin Neurosci 2011, 18:867-9, PMID: 21507657.

6. Walcott BP, Hanak BW, Caracci JR, Redjal N, Nahed BV, Kahle KT,

Coumans JV: Trends in inpatient setting laminectomy for excision of herniated intervertebral disc: Population-based estimates from the US nationwide inpatient sample. Surg Neurol Int 2011, 2(7), PMID: 21297929.

doi:10.1186/2045-8118-12-S1-017

Cite this article as: Hanak et al:: Towards a better understanding of the cellular basis for cerebrospinal fluid shunt obstruction: report on construction of a bank of explanted hydrocephalus devices. Fluids and Barriers of the CNS 2015 12(Suppl 1):017.

\section{Submit your next manuscript to BioMed Central and take full advantage of:}

- Convenient online submission

- Thorough peer review

- No space constraints or color figure charges

- Immediate publication on acceptance

- Inclusion in PubMed, CAS, Scopus and Google Scholar

- Research which is freely available for redistribution

Submit your manuscript at www.biomedcentral.com/submit
Biomed Central 